\title{
EDUCATION OF SCIENTISTS AND TECHNOLOGISTS FOR THE NEW AGE
}

\begin{abstract}
IN his presidential address to the Science Masters' Association in Manchester on January 2, Dr. B. V. Bowden, pointing out that Britain is already spending more than $£ 800$ million a year on education, or 4 per cent of the gross national product, questioned whether all this money was being spent properly, efficiently and on the right things, and whether enough or too much was being spent. In this context, he challenged strongly the meagre expenditure of about $£ 20,000$ in 1962 by the Ministry of Education to investigate the efficiency of educational progress. Even making the most generous allowance for expenditure by university departments of education, he doubted whether Britain's expenditure on educational research reached $\$ 250,000$ a year, and while he valued the impetus from the United States and the initiative and generosity of the Nuffield Foundation, most of the research into new syllabuses and text-books had still to be done. Education was, he thought, as profitable an investment as was open to any nation to-day, and this was especially true in respect of education in the underdeveloped countries.
\end{abstract}

Challenging next the belief of many schoolmasters that the universities provide courses in technology for boys who have no aptitude for science, Dr. Bowden, noting that science began in an attempt to solve practical problems and paying tribute to Sanderson's work at Oundle, insisted that science was much more than a body of knowledge; it was a way of life, a way of thought, and at its best only understood by active practitioners. He was concerned that so many of Britain's ablest schoolboys were interested in science but not in technology and engineering. While a successful engineer or technologist must know his science and be able to work with people, even to lead them, it was vital that schoolmasters should strive to persuade more of their pupils to take up the life of the creative technologist rather than that of the scientist. Few boys, in fact, even understood that technologists could be trained at a university. Finally, he thought there was room for a huge programme of research into methods of teaching and the possible effect of new techniques based on modern technology, including the study of the processes of learning and the use of television and films.

The full text of Dr. Bowden's address will be published in the March issue of The School Science Review, published. by the Science Masters' Association.

\section{RHEOLOGY OF MOTOR OILS}

\begin{abstract}
A $\mathbf{T}$ the meeting of the Cambridge Rheology Club held A on October 29, Mr. J. F. Hutton ('Shell' Research, Ltd.) spoke on "The Rheology of Motor Oils". He started by describing briefly the manufacture of lubricating oils from crude petroleum, continued with a discussion of lubricating oils as Newtonian liquids, and ended with a description of experimental work which has shown that lubricating oils, which are generally regarded as Newtonian liquids, can exhibit non-Newtonian effects and behave as visco-elastic liquids at very high rates of shear.

The most important property of a lubricating oil is its viscosity and the temperature of the oil is the external factor which has the greatest influence on viscosity. A rise in temperature of $1 \mathrm{deg}$. C causes a decrease in viscosity of the order of 5 per cent. It is desirable that the dependence of the viscosity of an engine lubricating oil on temperature should be reduced and this is achieved primarily by suitable refining. An additional reduction is obtained by dissolving in the oil about 1-3 per cent of a polymer having a weight-average molecular weight of $1-5 \times 10^{5}$. The most effective type of polymer is a copolymer made from oil soluble and oil insoluble monomers and so designed that its intrinsic viscosity, or thickening effect, increases as the temperature increases.

A.ddition of a polymer to an oil introduces non-Newtonian properties which, being of importance in lubrication, have been studied by many workers. However, in
\end{abstract}

the short time available, Mr. Hutton chose to talk about the more interesting problem, from the point of view of liquid. structure, of non-Newtonian effects in lubricating oils not containing polymers. The detection and measurement of such effects in capillary or Couette viscometers is a most difficult undertaking. Rates of shear greater

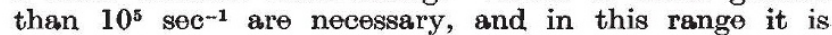
difficult to separate true shear rate thinning from a fall in viscosity due to viscous heating. A different approach to the problem has been made, notably by J. Lamb and A. J. Barlow, who, from measurements of the propagation of ultra-sonic shear waves through the oils have calculated their relaxation spectra. The results clearly demonstrate the visco-elastic nature of lubricating oils and indicate that the peaks in the spectra are characteristic of the types of molecule present.

In the discussion the comments and questions ranged widely from technological ones concerning the best oil to use in a motor-ear to more fundamental ones concerning heating effects in viscometry and the relation between experiments carried out in continuous shear and experiments carried out in oscillatory shear.

The next meeting of the club will be held on March 4 at the Technological Research Station, Spillers, Ltd., Station Road, Cambridge, when Mr. G. G. Zahler and Mr. G. R. Murfitt (Instron, Ltd.) will speak on "The Instron High Shear Capillary Rheometer". H. G. MULLER

\section{THE FISHERIES BIOCHEMICAL RESEARCH UNIT}

GOR some years the U.K. Development Commission 1 has sponsored a Unit for Biochemical Research bearing on the problems of fisheries, and at present located within the National Institute for Research in Dairying, Reading. In view of the retirement of the honorary director, Dr. S. K. Kon, within the next few years, the Development Commission has decided that it should be transferred to Aberdeen. The advantages of this new location are that the reconstituted Unit will be in close contact with the fishing industry, the University and the existing marine research institutes in Aberdeen. These are the Scottish Department of Agriculture and Fisheries Marine Laboratory and the Torry Research Station of the Department of Scientific and Industrial Research.

After consultation between the Development Commission and the University of Aberdeen, it was agreed 
that the Unit should be establishod within the University under the rgis of the professor of biological chomistry, Prof. W. O. Kermack. It is onvisaged that initially the staff would consist of five scientifie workers, including a director, who would be a reader in the University, and that members of the staff might take some part in the teaching activities of the University, although their primary obligation would be towards research. By this arrangement, the integration of research and advanced toaching would be assisted, and a mutually stimulating relationship establishod between the staff of the Unit and their colleagues in the University.

The two existing marine laboratorios in Aberdoon deal respectively with tho scientific and technological problems concornod with living fish in the sea, and with those involved in the storage and processing of fish in the period between catching and marketing. The objoct of the Fisheries Biochemical Research Unit will be tho investigation of the fundamental biochemistry of both marine and freshwater fish. Although the emphasis will be on the basic sciontific aspects, it is envisaged that this work will assist in the solution of problems of practical importance to the fishing industry.
It is proposod to plan and build a now laboratory to house this Unit in close proximity to the existing marine laboratories at Torry in Aberdeen. In order to facilitate this development, the Court of the University of Aberdeon has appointed Dr. P. T. Grant to the post of director of this Unit. Dr. Grant is at present a member of the staff of the Department of Biological Chemistry. It has boen arranged that this appointment will become operative at a later date, but meanwhile he will be directly concerned with the planning and oquipping of tho new laboratory.

Dr. Grant was a member of the staff at the National Institute for Medical Research during 1951-56 and worked with Sir Charles Harington and Dr. H. R. V. Arnstein on the biosynthesis of penicillin, and afterwards with Dr. J. D. Fulton on the comparative biochemistry of pathogenic protozoa. Since he has been in Aberdeen he has worked on the enzymology of the protozoa and in particular has been concerned with the components and mechanism of the unusual respiratory enzyme systems present in the brucei group of pathogenic African trypanosomes. He has also boon interested in the isolation and biosynthesis of mucopolysaccharides present in connective tissuo.

\title{
POSITIONS OF THE OXYGEN ATOMS IN UO
}

\author{
By B. T. M. WILLIS \\ Metallurgy Division, Atomic Energy Research Establishment, Harwell
}

$\mathrm{U}$ RANIUM dioxide, $\mathrm{UO}_{2}$, can dissolve oxygen at high temperatures to form the single phase $\mathrm{UO}_{2+x}$, where $x$ assumes any value in the range $0 \leqslant x \leqslant 0.25$. For $\mathrm{UO}_{2 \cdot 10}$ the temperature must exceed $600^{\circ} \mathrm{C}$ and for $\mathrm{UO}_{2 \cdot 20}$ the minimum temperature is about $1,050^{\circ} \mathrm{C}$ (rof. 1).

Neutron diffraction investigations have been made on a single-crystal of composition $\mathrm{UO}_{2 \cdot 13}$ with the aim of determining the positions of the oxygen atoms. The ratio of the slow neutron coherent scattering amplitudes of uranium and oxygen is $1 \cdot 47$, so that, unlike for X-rays, an appreciable proportion of the scattered intensity comes from oxygen. However, we must distinguish between oxygen atoms present in the $\mathrm{UO}_{2}$ crystal before oxidation and 'extra' oxygen atoms; as the former predominate, the location of the oxtra atoms is analogous to a lightatom determination with X-rays. In these circumstances very accurate neutron structure-factors are required, and it is necessary to correct the observed intensities for extinction (affecting the strong reflexions) and doubleBragg scattering (mainly affecting the woak reflexions).

All non-equivalent $h k k$ planes with an interplanar spacing greator than $0.53 \AA$ were measured at $800^{\circ} \mathrm{C}$, inside tho single-phase region of the phase diagram. No reflexions were observod other than those with $h, k$ both odd or both even, and so it was assumed in the analysis by least-squares and Fourier methods that the spacegroup is $F m 3 m$, as for $\mathrm{UO}_{2}$.

Table 1 summarizes the results of the least-squares analysis, which was carried out using a Mercury computer programme specially written for this work by Dr. J. S. Rollett. The oxygen atoms in $\mathrm{UO}_{2 \cdot 13}$ occupy throe different kinds of crystallographic site, and, as there are more equivalent positions for each site than oxygens to fill them, the oxygens are distributed at random among these positions. The programme allowed as adjustable parameters the probability of occupation of each atomic site, as well as the atomic co-ordinates and temperature factors. Altogether 11 parameters were obtained from 33 indopendent data, and the final 'discrepancy factor' $\left(\Sigma|| F_{\text {obs }}|-| F_{\text {cale }}|i \Sigma| F_{\text {obs }} \mid\right)$ was $2 \cdot 2$ per cent, which is close to the estimated accuracy of the individual data.
Table 1. Corstal Strectuke of vo $_{1 \cdot 1}$

\begin{tabular}{|c|c|c|c|}
\hline Atom & $\begin{array}{l}\text { Unit cell } \\
\text { co-ordinates }\end{array}$ & $\begin{array}{l}\text { Contribution to } \\
\text { formula unit } \\
\mathrm{U}_{m} \mathrm{O}_{n}\end{array}$ & $\begin{array}{c}\text { Temperature } \\
\text { factor } B \\
\left(\AA^{2}\right)\end{array}$ \\
\hline $\begin{array}{l}\text { Uranium } \\
\text { Oxygen O } \\
\text { Oxygen } 0^{\prime} \\
\text { Oxygen } 0^{*}\end{array}$ & 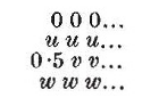 & $m=\left\{\begin{array}{l}1.00(0.01) \\
1.82(0.02) \\
0.08(0.05) \\
0.23(0.11)\end{array}\right.$ & $\begin{array}{l}1 \cdot 18(0.06) \\
1.45(0.08) \\
1.8(1 \cdot 6) \\
7.5(2.7)\end{array}$ \\
\hline
\end{tabular}

$(u=0.267(0.001), v=0.39(0.01), w=0.38(0.01)$. Space group $F m 3 m$. Standard deviations of parameters in brackets.)

The principal conclusions from Table 1 are as follows: (1) The composition determined from the scattering results is $\mathrm{UO}_{2 \cdot 13}$ in agreement with that found chemically. A more complete expression for the formula unit is:

$$
\mathrm{U}_{1 \cdot 00} \mathrm{O}_{1 \cdot 82} \mathrm{O}^{\prime}{ }_{0 \cdot 08} \mathrm{O}^{\prime \prime}{ }_{0 \cdot 23}
$$

where $\mathrm{O}, \mathrm{O}^{\prime}, \mathrm{O}^{\prime \prime}$ refer to oxygen atoms in the three kinds of site.

(2) The uranium atoms occupy the face-centred positions $000, \frac{1}{2} \frac{1}{2} 0, \frac{1}{2} 0 \frac{1}{2}, 0 \frac{1}{2} \frac{1}{2}$, and all these sites are filled. as in $\mathrm{UO}_{2}$.

(3) The $\mathrm{O}$ atoms at uuu ... are close to tho fluorite positions $\frac{111}{4} 4 . \ldots$, but are shifted slightly along $\langle 111\rangle$ towards the interstitial holes at $\frac{1}{2} \frac{1}{2} 2 \ldots$ (the $\frac{1}{2} \frac{1}{2} \frac{1}{2}, \frac{1}{2} 00$. $0 \frac{1}{2} 0,00 \frac{1}{2}$ positions are the largest holes in the $\mathrm{UO}_{2}$ lattice). The $\mathrm{O}$ atoms represent approximately nine out of ten of the original oxygens in $\mathrm{UO}_{2}$ before oxidation to $\mathrm{UO}_{2 \cdot 13}$; the remaining one-tenth are transferred during oxidation to $\mathrm{O}^{\prime}$ or $\mathrm{O}^{\prime \prime}$ positions.

(4) The interstitial atoms $\mathrm{O}^{\prime}$ and $\mathrm{O}^{\prime \prime}$ do not occupy the large interstitial holes at $\frac{1}{2} \frac{11}{2} \ldots$. . but positions about $1 \AA$ away.

Fourior analysis confirms tho least-squares results. Fig. 1 is a Fourier projoction, based on a Fourier series with the $F_{\text {obs }}$ data as coefficients, showing the uranium and oxygen $\mathrm{O}$ atoms. Fig. 2 is a difference Fourier projection, using $F_{\text {obs }}-F_{\text {ro }}$ as coefficients, where $F_{\text {CO }}$ is calculated for the uranium and $O$ atoms only. The contours in Fig. 2, which are on a much finer scale than in Fig. 1, show peaks representing the $O^{\prime}$ atoms at $0 \cdot 5$ vv . . . and $\mathrm{O}^{\prime \prime}$ atoms at www . . . 